\title{
Allogenic mesenchymal stem cell intravenous infusion in reparation of mild intestinal ischemia/reperfusion injury in New Zealand rabbits ${ }^{1}$
}

\author{
Alvaro P.L. Oliveira ${ }^{2 *}$, Julia P.P. Rangel ${ }^{2}$, Viviane Raposo ${ }^{3}$, \\ Noely G. Pianca ${ }^{4}$, Emanuelle P. Cruz ${ }^{4}$, Evandro Pereira Neto ${ }^{2}$, \\ Wagner A.B. Fiorio ${ }^{2}$ and Betânia S. Monteiro ${ }^{5}$
}

\begin{abstract}
Oliveira A.P.L, Rangel J.P.P., Raposo V., Pianca N.G., Cruz E.P., Pereira Neto E., Fiorio W.A.B \& Monteiro B.S. 2018. Allogenic mesenchymal stem cell intravenous infusion in reparation of mild intestinal ischemia/reperfusion injury in New Zealand rabbits. Pesquisa Veterinária Brasileira 38(4):710-721. Departamento de Medicina Veterinária, Universidade Vila Velha, Rua Comissário José Dantas de Melo 21, Vila Velha, ES 29102-920, Brazil. E-mail: oliveira.medvet@hotmail.com

The present study aimed to evaluate the efficacy of mesenchymal stem cell (MSC) infusion, derived from adipose tissue, on reduction of local and remote tissue damage caused by the event of experimental intestinal I/R in New Zealand breed rabbits. For obtaining, characterization, and cultivation of MSC derived from adipose tissue (MSC-Adp), 3 juvenile animals (four months old) were used. The cells were considered to be viable for therapy after the fourth passage (in vitro phase). For the in vivo stage, 24 young adult animals (six months old) were used, weighing approximately $3.5 \mathrm{~kg}$, in which were randomly divided into two groups, called: IR treated with MSC (I2H/R5H MSC 3D; I2H/R5H MSC 7D); IR treated with PBS (I2H/R5H PBS 3D; I2H/R5H PBS 7D). The animals were anesthetized and submitted to pre-retro-umbilical midline celiotomy. The extramural peri-intestinal marginal artery was located and clamped (predetermined and standardized region) with the aid of a vascular clip, promoting a 2 hour blood flow interruption. After this period, blood flow was reestablished, inhalatory anesthesia was suspended, and the animals awaken. After 5 hours of reperfusion, the treatments were performed by intravenous infusion according to the experimental groups. The animals were evaluated 72 hours and seven days after the treatment as for the macroscopic appearance (color and peristaltism) of the jejunal segment, and by histological evaluation of the ischemic segment for the presence or absence of destruction of the intestinal mucosa, edema, bleeding, dilation of lymph vessels, and presence of polymorphonuclear inflammatory cells, both in the mucosa and submucosa. The observed results revealed that the groups treated with MSC-Adp obtained smaller mucosal and submucosal lesions when compared to the groups treated with PBS. Also, MSC-Adp treated groups obtained controlled inflammatory response and higher mitotic rate, outcomes related to the therapeutic potential of MSC. Infusion of stem cells attenuated the lesions caused by intestinal I/R in both MSC groups when compared to the group treated with PBS.
\end{abstract}

INDEX TERMS: Mesenchymal stem cell, intravenous infusion, intestinal ischemia, New Zealand rabbit, remote injury, cell therapy, extramural peri-intestinal marginal artery, clinics.

\footnotetext{
${ }^{1}$ Received on August 1, 2017.

Accepted for publication on September 5, 2017.

${ }^{2}$ Mestre em Ciências Animais, Laboratório de Terapia Celular e Células Tronco, Departamento de Medicina Veterinária, Universidade Vila Velha (UVV), Rua Comissário José Dantas de Melo 21, Vila Velha, ES 29102-920, Brazil. * Corresponding Author: oliveira.medvet@hotmail.com

${ }^{3}$ Mestrando em Ciências Animais, Laboratório de Terapia Celular e Células, Departamento de Medicina Veterinária, Universidade Vila Velha (UVV), Rua Comissário José Dantas de Melo 21, Vila Velha, ES 29102-920.
}

\footnotetext{
${ }^{4}$ Graduando em Medicina Veterinária, Iniciação Científica, Laboratório de Terapia Celular e Células, Departamento de Medicina Veterinária, Universidade Vila Velha (UVV), Rua Comissário José Dantas de Melo 21, Vila Velha, ES 29102-920.

${ }^{5}$ Docente do Programa de Pós-Graduação em Ciências Animais, Coordenador do Grupo de Pesquisa, Laboratório de Terapia Celular e Células, Departamento de Medicina Veterinária, Universidade Vila Velha (UVV), Rua Comissário José Dantas de Melo 21, Vila Velha, ES 29102-920.
} 
RESUMO.- [Infusão intravenosa de células tronco mesenquimais alógenas na reparação da lesão branda de isquemia/reperfusão intestinal em coelhos Nova Zelândia.] 0 presente estudo teve como principal objetivo avaliar a eficácia da infusão células tronco mesenquimais (CTM) derivada de tecido adiposo sobre diminuição das lesões teciduais locais e remotas, causadas pelo evento de I/R intestinal experimental, em coelhos da raça Nova Zelândia. Para obtenção, cultivo e caracterização das CTM provenientes de tecido adiposo (ADCTM) foram utilizados 3 animais jovens. As células foram consideradas viáveis para terapia a partir da quarta passagem (fase in vitro). Para etapa in vivo foram utilizados 24 animais, adulto-jovens, pesando aproximadamente $3,5 \mathrm{~kg}$, divididos aleatoriamente em dois grupos experimentais, denominados IR Tratado com CTM (I2H/R5H CTM 3D; I2H/R5H CTM 7D); IR Tratado PBS (I2H/R5H PBS 3D; I2H/R5H PBS 7D). Os animais foram anestesiados e submetidos à celiotomia mediana pré-retroumbilical. A artéria marginal peri-intestinal extramural foi localizada e clampeada (região predeterminada e padronizada) com auxílio de um clipe vascular, promovendo uma interrupção do fluxo sanguíneo durante 2 horas. Após esse período, o fluxo sanguíneo foi restabelecido, a anestesia inalatória suspendida e os animais despertados. Após 5 horas de reperfusão realizou-se os tratamentos por infusão endovenosa, conforme grupos experimentais. Os animais foram avaliados 72 horas e sete dias após o tratamento quanto ao aspecto macroscópico (coloração e peristaltismo) do segmento jejunal e por meio de avaliação histológica do segmento isquemiado quanto à presença ou ausência de destruição de mucosa intestinal, edema, hemorragia, dilatação de vasos linfáticos e presença de células inflamatórias polimorfornucleares, tanto em mucosa quanto submucosa. Os resultados observados revelaram que os grupos tratados com ADCTM obtiveram menores lesões em mucosa e submucosa quando comprados aos grupos tratados com PBS. Ainda os grupos tratados com ADCTM obtiveram resposta inflamatória controlada e maior taxa mitótica, resultados relacionados ao potencial terapêutico das CTM.

TERMOS DE INDEXAÇÃO: Células tronco mesenquimais, isquemia intestinal, coelho Nova Zelândia, lesões remotas, terapia celular, artéria marginal peri-intestinal extramural, clínica.

\section{INTRODUCTION}

Ischemia/reperfusion $(\mathrm{I} / \mathrm{R})$ intestinal injuries are considered to be events of great clinical relevance which may cause local and remote damage (Gao et al. 2006, Jiang et al. 2011, Vollmar $\&$ Menger 2011, Ben et al. 2012). Intestinal ischemia may be classified into acute mesenteric ischemia, chronic mesenteric ischemia, and ischemic colitis which culminate in decreased blood supply to tissues and reduced intestinal oxygen (Rowe \& White 2002, Yasuhara 2005, Kaszaki et al. 2006).

Knowing that the small intestine consists of labile cells considered to be sensitive to ischemic insult, once intestinal I/R occurs the barrier function may become impaired and may even lead to a bacterial translocation (Hung et al. 2004, Chen et al. 2014), systemic inflammatory response syndrome, and multiple organ failure (Kubiak et al. 2010, Ma et al. 2014).

Due to the high mortality rate, $60-80 \%$ (Ritz et al. 2005, Boybeyi et al. 2014) and morbidity, 60-100\% (Oldenburg et al. 2004, Jiang et al. 2011) caused by intestinal I/R, studies become increasingly more necessary in order to elucidate the mechanisms involved in the event and its possible therapeutic measures (Rocha et al. 2012).

Among the therapeutic modalities able to mitigate the harmful effects of local and remote I/R, there are the use of: antioxidants and anti-inflammatory medications (Kostopanagiotou et al. 2007, Avgerinos et al. 2010, Yurdakan et al. 2012), use of propofol (Vasileiou et al. 2012), green tea (Abdeen et al. 2011), hydrocortisone (Alves et al. 2011), rutin (Itagaki et al. 2010), glutamine (Pagliosa et al. 2009), methylene blue (Greca et al. 2008), dimethyl sulfoxide (DMSO) (Dabareiner et al. 2005), copaiba oils (Paiva et al. 2004), among others.

Studies of cellular therapies for inflammatory intestine diseases are increasingly emerging due to its multifocal action. Among the disorders which are primary targets of these studies, there are: the inflammatory bowel disease, short bowel syndrome, and I/R injuries. The term " multifocal " used to define these types of therapy is related to the fact that they decrease inflammation, reduce risk of infection, and stimulate tissue repair (Manieri \& Stappenbeck 2011). Based on these principles, the use of mesenchymal stem cells (MSC) as a treatment of intestinal diseases (Manieri \& Stappenbeck 2011, Jiang et al. 2011) is being tested.

Mesenchymal stem cells (MSC) are present in all adult tissues, in the perivascular region, but in small quantities (Meirelles et al. 2008).These are multipotent cells capable of adhering to plastic substrate, and differentiate in vitro into various cell types including: osteoblasts, chondroblasts, hepatocytes, neurons, epithelial cells, renal and cardiac cells, among others (Pittenger et al. 1999, Monteiro et al. 2008, Manieri \& Stappenbeck 2011). Also due to this characteristic of plasticity, these cells are able to differentiate either in vitro or in vivo (Giordano et al. 2007).

The mesenchymal cells are capable of promoting immunomodulation through the stimulation of several growth factors, these being, the vascular endothelial growth factor (VEGF), insulin-like growth factor 1 (IGF-1), hepatocyte growth factor (HGF), epidermal growth factor (EGF), and transforming growth factor-alpha (TGF- $\alpha$ ). The activation of these factors will result in inhibition of apoptosis, increased angiogenesis; they stimulate mitosis, proliferation, and differentiation of these cells into intrinsic organ precursors (Jiang et al. 2011).

The aim of this study was to evaluate through histopathological results, if the infusion of allogenic mesenchymal stem cells, derived from adipose tissue, intravenously, will migrate local and remote intestinal I/R injury in rabbits experimentally subjected to intestinal ischemia, after occlusion of the cranial mesenteric artery.

\section{MATERIALS AND METHODS}

Ethics statement. The study was conducted according to the standards of the Brazilian College of Animal Experimentation (COBEA) and was approved by the Ethics Committee, Bioethics and Animal Welfare (CEUA) of the University Vila Velha (UVV), process 294/2014.

Experimental animals. For the study $27 \mathrm{New}$ Zealand breed male rabbits were used, with ages of approximately 10 weeks, and average weight of $3.0 \mathrm{~kg}$, allocated in a modified container of 12 meters in length, lined with PVC and thermal insulation, with air conditioning and exhaust to control the temperature (approximately $20^{\circ} \mathrm{C}$ ), and electric timer keeping a photoperiod of 12/12 hours light and 
dark. Three animals were used in the in vitro stage of the study and 24 animals were allocated in the in vivo study.

The animals were kept in individual cages, randomly distributed, and receiving water ad libtum and 100 grams/day of commercial rodent chow (Ração do Sítio Coelhão ${ }^{\circledR}$, Guabi Nutrição Animal, Anápolis, GO).

Cell culture. Adipose tissue was collected from three rabbits. Preceding the tissue collection, the animals were kept in food restriction for 12 hours, and then subjected to preanesthetic medication with acepromazine $(0.1 \mathrm{mg} / \mathrm{kg} / \mathrm{IV})$ associated with morphine $(0.4 \mathrm{mg} / \mathrm{kg} / \mathrm{IM})$. After ten minutes, they underwent trichotomy on the right forelimb, sternal and abdomen regions, then, in the operating room, the marginal auricular vein was catheterized and drugs for induction of anesthesia were administered: propofol $(2 \mathrm{mg} / \mathrm{kg} / \mathrm{IV})$ and midazolam $(1 \mathrm{mg} / \mathrm{kg} / \mathrm{IV})$. After the loss of reflexes, adipose tissue samples of approximately $1.0 \mathrm{~cm}^{3}$ (1.0 grams) were extracted from the inguinal region, under aseptic conditions, and stored in a falcon tube containing $50.0 \mathrm{ml}$ cell culture medium.

This tissue was cut into small pieces in a laminar flow, and transferred to another falcon tube containing $15.0 \mathrm{ml}$ of type I collagenase solution (Sigma, St. Louis MO, USA) for 60 minutes in an incubator at $37^{\circ} \mathrm{C}$, and $5 \% \mathrm{CO} 2$, agitated every 15 minutes. Subsequently, the tube was centrifuged at 694G (2000 rpm) for 10 minutes, the supernatant was discarded and the pellet was resuspended in $10.0 \mathrm{ml}$ of DMEM (Dulbecco's Modified Eagle Medium) supplemented with FBS (Fetal Bovine Serum) and Antibiotic Antimycotic Solution (100x) (1ml/100ml DMEM), and this volume divided into five $75 \mathrm{~cm}^{2}$ culture bottles.

To the bottles, complete DMEM was added to complete the volume of $15.0 \mathrm{ml}$ and the bottles were maintained in an incubator at $37^{\circ} \mathrm{C}$ in $5 \% \mathrm{CO}_{2}$ and $95 \%$ humidity. Cells were monitored daily in inverted phase contrast microscope, and the culture medium changed every 2 to 3 days according to cell metabolism.

After remaining in the incubator, when the confluence of $80 \%$ was identified, the culture medium was discarded completely, and the culture was trypsinized (1X Trypsin-EDTA) and incubated at $37^{\circ} \mathrm{C}$ for 5 minutes. After this period, the trypsin action was inactivated with the addition of complete DMEM. The solution was transported to a centrifugal tube and centrifuged at a temperature of $22^{\circ} \mathrm{C}$ and $694 \mathrm{G}$ (2000 rpm) for 10 minutes. The supernatant was completely discarded and the pellet resuspended in complete DMEM medium, and again split into culture bottles in 1:2 ratios (each one formed two new bottles). With every new confluence of $80 \%$ the procedure was performed again until the fourth cellular passage.

Cell characterization. An aliquot of the fourth passage cells, derived from adipose tissue, was characterized using a flow cytometric through analysis of the expression of surface cell molecules to CD73 (anti-CD73 clone5F/B9mouse-AbCam Cambridge,Massachusetts,USA), CD 11 (anti-CD11b-AbCam), CD 90 (anti-CD90 clone 0x-7 mouse - AbCam), and CD 45 (anti-CD45 clone 69 mouse - BD Bioscience, San Jose, California, USA) using a FACScan flow cytometer and CellQuest ${ }^{\circledR}$ software, yielding 30,000 events per sample tested.
Osteogenic differentiation. Another aliquot of fourth passage cells was subjected to stages of osteogenic differentiation. Adherent cells were detached with trypsin, counted, and replated in 6-well plates with $22 \mathrm{~mm}$ in diameter glass coverslips, and with DMEM culture medium supplemented with $10 \%$ FBS, $10^{-8} \mathrm{~mol} / \mathrm{mL}$ of dexamethasone (Sigma, St. Louis MO, USA), 5.0 $\mu \mathrm{g} / \mathrm{ml}$ ascorbic acid 2-phosphate (Sigma, St. Louis MO, USA), and 10,0 mmol/L of $\beta$-glycerophosphate (Sigma, St. Louis MO, USA), and incubated at $37^{\circ} \mathrm{C}$ for four weeks.

On the 30th day after placing the cells in osteogenic medium, the coverslips were washed in PBS and stained by the Von Kossa method for observation of calcium deposition.

Cell preparation for infusion. After the fourth passage, other cell samples were trypsinized, observed under optical microscopy to evaluate cell viability, subjected to a Neubauer counting chamber, and aliquoted at a concentration of $1.2 \times 10^{6}$ cells $/ 0.5 \mathrm{ml}$ of PBS. Each aliquot was stored in a $1.0 \mathrm{ml}$ syringe and transported to the operating room, until infusion.

Anesthetic procedures. The rabbits were kept on feed withdrawal for 8 hours. Prior to the surgery, pre-anesthetic drugs were administered associating Xylazine $(2.5 \mathrm{mg} / \mathrm{kg} / \mathrm{IM})$ and Ketamine $(25 \mathrm{mg} / \mathrm{kg} / \mathrm{IM})$. The marginal auricular vein was cannulated for the establishment of fluid therapy and implementation of analgesia with Tramadol hydrochloride $(1.0 \mathrm{mg} / \mathrm{kg} / \mathrm{IM})$. After the loss of both eyelid and laryngotracheal reflexes, tracheal intubation was performed to allow the maintenance of anesthesia by dose effective inhalation of isoflurane. The central auricular artery was catheterized, heparinised, and the catheter connected to a system for blood pressure measuring and to allow anesthetic monitoring.

The patient was placed in a supine position, propped up on surgical chute and submitted to a broad trichotomy of the abdominal region.

Surgical procedure. The surgical field was prepared by performing antisepsis with $70 \%$ alcohol and $2 \%$ topical chlorhexidine topical, and the surgical drapes were positioned. Pre-retro-umbilical midline celiotomy was performed measuring approximately $6.0 \mathrm{~cm}$ in a cranial-caudal direction. The intestinal segment of the jejunum, most proximal to the incision, was identified and exteriorized from the cavity and the extramural peri-intestinal marginal artery/vein branch and occlusion performed using a vascular clip.

The occlusion time consisted of two hours of ischemia and five hours of reperfusion. During the occlusion time interval, the animals remained anesthetized and had their abdominal cavity sutured by separate stitches, to prevent loss of abdominal fluid, and contamination. After removal of the vascular clip, the muscle fascia was approximated with the Sultan stitch suture (X); the subcutaneous tissue, with the simple continuous suture; and the skin was approximated by intradermal suturing. Synthetic non-absorbable sutures were used on all tissue layers.

Experimental groups and treatments. The animals were numbered from 1 to 24 , and were distributed randomly into the experimental groups containing twelve animals (Table 1). The order of the surgeries obeyed the pre-established numbers.

Table 1. Summary/proposed design for preparation of the experimental groups

\begin{tabular}{|c|c|c|c|c|}
\hline Group & No. of animals & Ischemia/Reperfusion duration & Treatment time & Euthanasia (Moments/time) \\
\hline \multirow[t]{2}{*}{ I2H/R5H PBS } & 6 & 2 hours/5 hours & Immediately after reperfusion & 3 days after treatment \\
\hline & 6 & & & 7 days after treatment \\
\hline \multirow[t]{2}{*}{ I2H/R5H MSC } & 6 & 2 hours $/ 5$ hours & & 3 days after treatment \\
\hline & 6 & & & 7 days after treatment \\
\hline
\end{tabular}


(a) Two hour ischemia/five hour reperfusion + intravenous administration of phosphate buffered saline (I2H/R5H PBS) group: Patients submitted to pre-retro-umbilical midline celiotomy and manipulation of the intestinal segment of the jejunum, then vessel occlusion for 2 hours. The animals remained anesthetized for two hours and after this time the vascular clip was removed, and suture in the mesentery near the clamping site was performed using a blue polypropylene non-absorbable synthetic suture. This moment was considered to be the beginning of reperfusion, anesthesia was stopped and the patient remained alive and awake. After the 5 hour period of intestinal reperfusion, treatment was performed with an intravenous infusion of $0.5 \mathrm{ml}$ of PBS using the marginal auricular vein.

At three and seven days after surgery, six animals (in each period) were submitted again to midline celiotomy to collect intestinal fragments for histological appraisal, peritoneal swabs for bacterial translocation test, then the animals were sacrificed by anesthetic overdose.

(b) Two hour ischemia/five hour reperfusion + intravenous administration of mesenchymal stem cells (I2H/R5H MSC) group: Patients submitted to pre-retro-umbilical midline celiotomy and manipulation of the intestinal segment of the jejunum, then vessel occlusion for 2 hours. The animals remained anesthetized for two hours and after this time the vascular clip was removed, and suture in the mesentery near the clamping site was performed using a blue 5-0 polypropylene non-absorbable synthetic suture. This moment was considered to be the beginning of reperfusion, anesthesia was stopped and the patient remained alive and awake. After the 5 hour period of intestinal reperfusion, treatment was performed with an intravenous infusion of mesenchymal stem cells $\left(1.2 \times 10^{6}\right.$ cells $)$ suspended in $0.5 \mathrm{ml}$ of PBS using the marginal auricular vein.

At three and seven days after surgery, six animals (in each period) were submitted again to midline celiotomy to collect intestinal fragments for histological appraisal, peritoneal swabs for bacterial translocation test, then the animals were sacrificed by anesthetic overdose.

Trans-surgical macroscopic evaluation. Before and after clamping of the extramural peri-intestinal marginal artery/vein, the macroscopic aspect of the segment irrigated by the occluded branch and adjacent segments was evaluated regarding color, peristalsis ("pinch test"), and temperature to touch. Macroscopic findings were compared between animals of the same group, as well as between groups.

Evaluation of bacterial translocation (BT). To evaluate possible bacterial translocation, peritoneal swabs were performed after midline celiotomy (baseline); after removal of the vascular clip (ischemia); and during the second surgical procedure, after 3 or 7 days post-treatment. Cultures were expressed as colony forming units (CFUs) and bacterial translocation was seen when cultures grew in the intestinal samples collected.

Histopathological examination. Three intestinal fragments of the jejunum, measuring approximately $3.0 \mathrm{~cm}$ in length, were collected through enterectomy, in which one fragment was of the region affected by ischemic injury, another fragment $10 \mathrm{~cm}$ cranial to the ischemic injury, and another $10 \mathrm{~cm}$ caudal to the ischemic injury. After the collection, the animals were euthanized.

All the extracted fragments were fixed in $10 \%$ formalin and embedded in paraffin. Tissues were sectioned in cuts at approximately 4-5 $\mu \mathrm{m}$ for confection of histological slides, and stained with hematoxylin and eosin.

Histologically, at least six randomly chosen fields were evaluated per slide for each animal as well as for each segment, and the median of the events considered in order to classify the injuries into scores. The evaluator was unaware of the evaluated groups.

The histopathological classification of the injuries from the ischemic fragment was established according to an adaptation of the score proposed by Chiu et al. (1970), shown in Table 2, as well as an adaptation of Pagliosa et al. (2009), shown in Tables 3 and 4. To evaluate the presence of a mononuclear inflammatory process, a score was established (Table 5). Descriptive analysis of the lesions found in each group was also conducted.

Table 2. Injury score of jejunum mucosa belonging to New Zealand rabbits subjected to ischemia and reperfusion by clamping of the extramural peri-intestinal marginal artery/vein

\begin{tabular}{cl}
\hline Score & \multicolumn{1}{c}{ Injury } \\
\hline 0 & Mucosa unchanged \\
1 & $\begin{array}{l}\text { Villi preserved without cell lysis, without inflammatory } \\
\text { process (IP), and with subepithelial space (SE) }\end{array}$ \\
2 & Cell lysis, with SE, increased spacing between the villi \\
3 & Villi denudation with inflammatory cells (IC), dilated capillaries \\
4 & $\begin{array}{l}\text { Structural destruction of the villi, with IC, basal glandular } \\
\text { necrosis and ulceration }\end{array}$ \\
5 & Total destruction of the mucosa
\end{tabular}

Table 3. Score for edema, hemorrhage and presence of polymorphonuclear cells in the mucosa and submucosa of the jejunum in New Zealand rabbits subjected to ischemia and reperfusion by clamping of the extramural peri-intestinal marginal artery/vein

\begin{tabular}{cc}
\hline Score & Edema/hemorrhage/presence of polymorphonuclear cells \\
\hline 0 & Absent \\
1 & Incipient \\
2 & Light \\
3 & Moderate \\
4 & Intense
\end{tabular}

Adapted from Pagliosa et al. (2009).

Table 4. Score for lymphatic vessel dilatation in the mucosa and submucosa of the jejunum in New Zealand rabbits subjected to ischemia and reperfusion by clamping of the extramural peri-intestinal marginal artery/vein

\begin{tabular}{cc}
\hline Score & Lymphatic dilatation \\
\hline 0 & Absent \\
1 & Moderate \\
2 & Intense
\end{tabular}

Adapted from Pagliosa et al. (2009).

Table 5. Score for mononuclear inflammatory process in the mucosa and submucosa of the jejunum in New Zealand rabbits subjected to ischemia and reperfusion by clamping of the extramural peri-intestinal marginal artery/vein

\begin{tabular}{cc}
\hline Score & Mononuclear inflammatory process \\
\hline 0 & Absent \\
1 & Incipient \\
2 & Light \\
3 & Moderate \\
4 & Intense
\end{tabular}


Statistical analysis. The Kolmogorov-Smirnov test was used to test the normality of the histopathological data classified in scores. Then, the data was evaluated using the nonparametric Kruskal-Wallis test, followed by Dunn's post-test, and considered significant when $p<0.05$. Data was analyzed using the GraphPadPrism $5^{\circledR}$ program.

\section{RESULTS}

The adipose tissue led to a heterogeneous culture, consisting of rounded non-adherent cells, and lipid micelles in the supernatant, in the early hours of culture. After 24 hours, cells with fibroblastoid morphology and adhesion to the bottle were observed; and after three days, the cell population had become more homogenous, with a prevalence of adherent cells with fibroblastoid morphology and organized into colonies (Fig.1A,B), remaining similar during all times of observation. Cell viability presented by the Trypan Blue test was greater than $95.2 \%$.
Phenotypic characterization, obtained by flow cytometry, showed low expression of CD45 hematopoietic cell markers (6.17\%), and CD11 (3.63\%); and high expression of CD90 stem cell markers (99.0\%) and CD73 (96.7\%). During the osteogenic differentiation stage, calcification points (Fig.1C) of the matrix, from the seventh day after differentiation induction were observed; and the cells that suffered differentiation, changed from an elongated fibroblastoid appearance, to a more rounded shape. The presence of extracellular matrix, rich in calcium, due to the observation of reddish mineralization nodules, after Von Kossa staining, was evidenced on the 30th day (Fig.1D).

The association of these data, allowed us to infer that, the group of cells used in the study are from mesenchymal stem cells.

The anesthetic induction procedure was performed in order not to cause excitement of the animals so that the hemodynamic and respiratory functions remain stable until

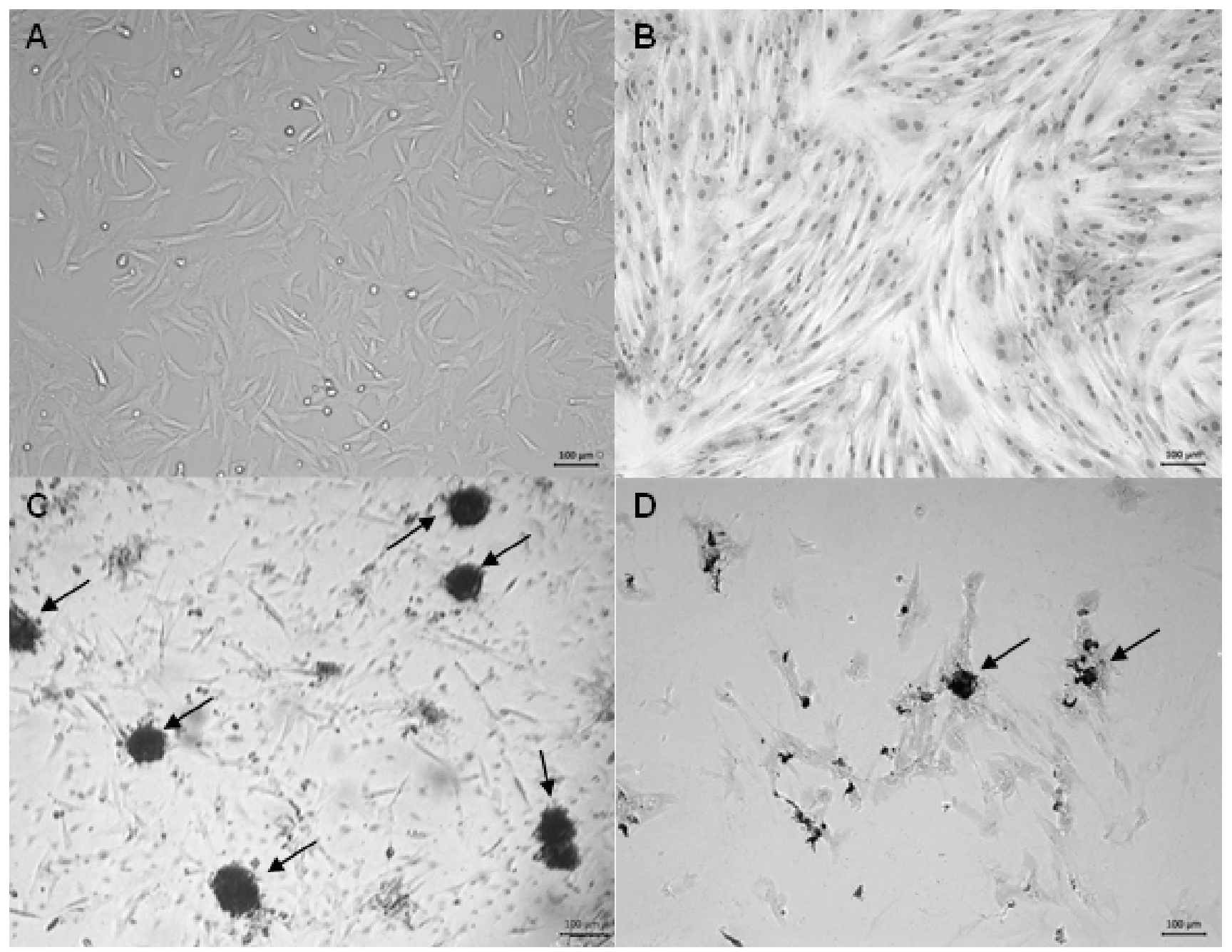

Fig.1. Optical microscopic image showing mesenchymal cell culture derived from rabbit adipose tissue. (A) Presence of elongated cells with fibroblastoid morphology and adhered to the plastic substrate of the bottle, demonstrating greater than $80 \%$ cell confluence. (B) Fourth passage cell culture with presence of elongated cells, with fibroblastoid morphology and adhered to the plastic substrate of the bottle, stained with Giemsa technique. (C) Fourth passage cell culture, submitted to osteogenic differentiation presenting calcification points (arrow) of the matrix on the seventh day after differentiation induction. (D) Fourth passage cell culture, submitted to osteogenic differentiation displaying presence of extracellular matrix rich in calcium and observation of reddish mineralized nodules by Von Kossa staining on the 30 th day. Bar $=100 \mu \mathrm{m}$. 
the time of the procedure. In some animals intubation could not be performed, so these were kept with the aid of a mask. No anesthetic complications were observed.

The clamping of the extramural peri-intestinal marginal artery/vein, allowed occlusion of blood flow to a segment of approximately $8 \mathrm{~cm}$ in length, providing after two hours, discoloration of the intestinal serosa, and therefore suggesting congestion and hypomotility. The adjacent regions (10 cm cranial and $10 \mathrm{~cm}$ caudal) to the irrigated area, presented slightly changed. The average time of surgery, considering from the skin incision to the end of the suture, was 2 (two) hours and thirty (30) minutes.

Due to the methodology applied, the macroscopic alterations related to the reperfusion event were not evaluated, since when the ischemia period ended, the anesthesia was ceased; the animals were housed in cages; and observed for five hours, until the time of the treatment by intravenous infusion and then kept under observation up to three or seven days, according to the experimental group.

At three or seven days, the animals were again subjected to midline celiotomy. The use of a 5-0 polypropylene non-absorbable synthetic suture, to mark the site of injury was shown viable, due to the fact that when the animals underwent surgery again it was possible to easily identify the marked location. Macroscopically, in both I2H/R5H MSC groups, it was observed that the intestinal serosa in the entire jejunal segment showed to be an intense red color and the presence of blood vessels were clearly evident (Fig.2A); and in response to the "pinch test", the ischemic intestinal segments and the segments adjacent to the site of injury, showed positive results.

In the groups I2H/R5H PBS 3D, and I2H/R5H PBS 7D, there was evidence of free fluid in the abdominal cavity, of a serous aspect and yellow color. Two animals from the group I2H/R5H PBS 7D showed the presence of fibrin deposits in the intestinal serosa, and some intestinal segments attached to the other (Fig.2B). This was not observed in the other groups.
Also, in the PBS groups, the "pinch test" on the ischemic and adjacent intestinal segments showed responses suggestive of dysmotility.

No bacterial growth was found in cultures made from peritoneal swabs, in any of the evaluation moments.

Histologically, considering the intestinal mucosal injuries, it was noted that in the groups treated with PBS, villi sites with subepithelial spaces (score 1) and cell lysis (score 2) were evidenced (Fig.3), while no change was displayed in the MSC groups. Groups I2H/R5H MSC 3D and I2H/R5H MSC 7D showed significant difference compared to the groups I2H/R5H PBS 3D and I2H/R5H PBS 7D. The findings are shown in Table 6.

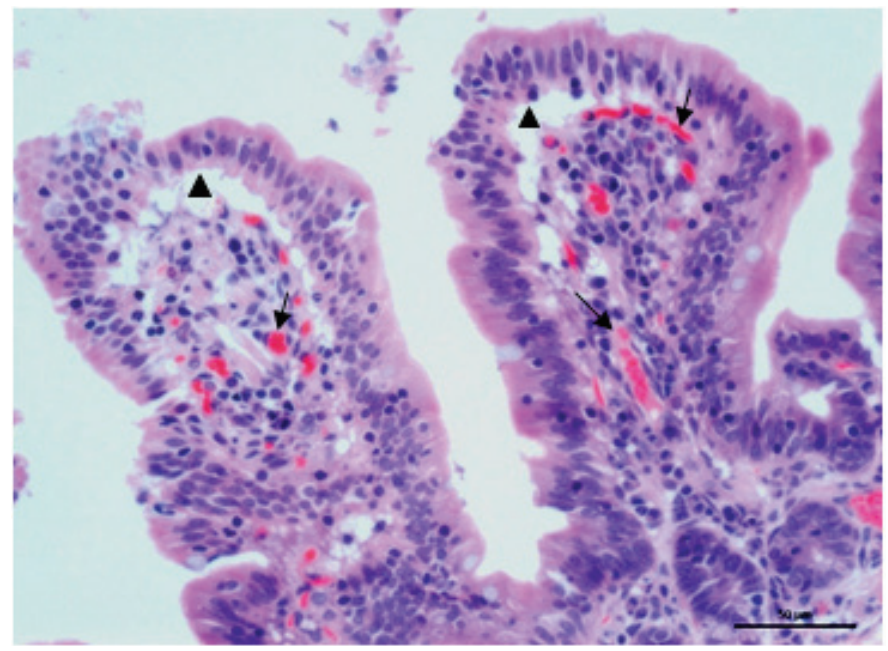

Fig.3. Photomicrography of an animal allocated in group I2H/R5H PBS 7D exhibiting subepithelial space (triangle) in intestinal mucosa region, classified as score 2 and incipient hemorrhage (score 1) (arrows).

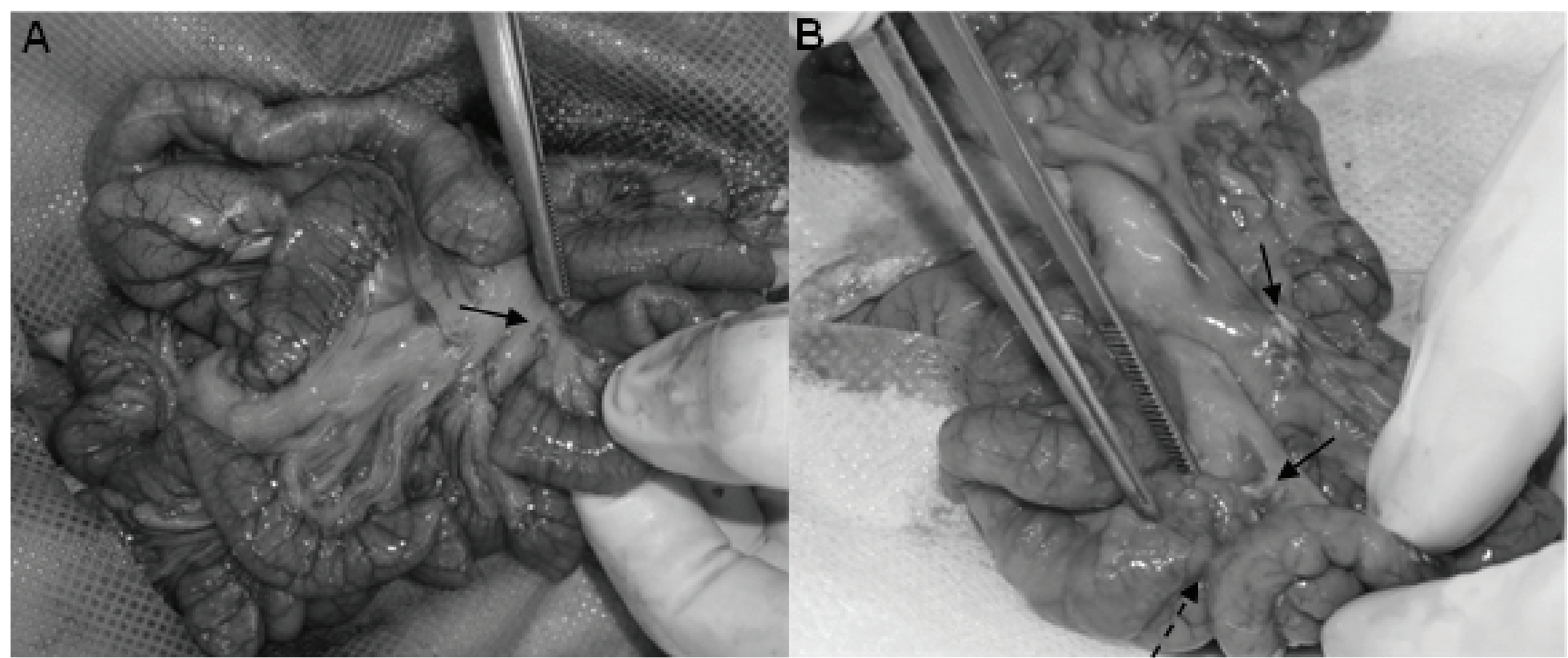

Fig.2. Jejunal segment belonging to allocated animals subjected to two hours of ischemia and five hours of reperfusion (I2H/R5H). (A) Group I2H/R5H MSC 7D - intestinal serous of whole jejunal segment with intense red color and presence of very evident blood vessels. Arrow showing the mesentery suture indicating site of blood vessel occlusion. (B) Group I2H/R5H PBS 7D - intestinal serous of whole jejunal segment with intense red color, presence of very evident blood vessels, and the presence of fibrin deposits in the intestinal serosa (arrow), and some intestinal segments adhered to the other (dashed arrow). 
Regarding the erosion of mucosa, most of the observations noted were of erosion absence (score 0 ), only in the groups treated with PBS was it possible to observe separation of the epithelium and lamina propria in the tips of the villi (score 1 ). There was no statistical difference between groups.

For the evaluated variable: mucosal edema, the groups I2H/R5H MSC 3D and I2H/R5H MSC 7D showed standard classification of missing/incipient (score 0-1), and were significantly different from the I2H/R5H PBS 3D group, with $p<0.05$ and $p<0.01$ respectively, showing mild to moderate degrees (Fig.4). It was also observed that this mucosal edema tended to resolve over the seven days of observation.

Considering the variable mucosal hemorrhage, most observations were classified in scores of 0 (absent), with rare findings of light hemorrhage (score 2). No statistical difference was observed between the groups.

Regarding the presence of polymorphonuclear infiltrate, low scores (score 2) and moderate scores (score 3) were more frequently noted in the groups I2H/R5H MSC 3D and I2H/R5H MSC 7D. There was a statistical difference between the group $\mathrm{I} 2 \mathrm{H} / \mathrm{R} 5 \mathrm{H}$ MSC in relation to the groups $\mathrm{I} 2 \mathrm{H} / \mathrm{R} 5 \mathrm{H}$ PBS 3D $(p<0.05)$ and I2H/R5H PBS 7D $(p<0.001)$. The other remaining alterations are presented in Table 7.

The presence of a mononuclear inflammatory process was observed in groups I2H/R5H MSC 3D and I2H/R5H MSC 7D, classified primarily as incipient (score 1) and moderate (score 3), respectively. Based on the result, there was significant difference between the groups I2H/R5H MSC 3D compared to the group I2H/R5H MSC 7D $(p<0.01)$. The other remaining alterations are presented in Table 8.

For the variable dilation of lymphatic in mucosa, the group I2H/R5H MSC 3D was classified as incipient for the most part. The group I2H/R5H MSC 7D was classified as absent. The groups I2H/R5H PBS 3D and I2H/R5H PBS 7D had incipient (score 1) and light (score 2) classifications, respectively. Statistically the I2H/R5H MSC 7D group was different from the groups I2H/R5H PBS 3D $(p<0.05)$ and I2H/R5H PBS 7D $(p<0.05)$. The other remaining alterations are presented in Table 9.

The histopathological findings showed submucosal edema classified as incipient (score 1) to absent (score 0) in the groups treated with MSC (Fig.5). Different from that

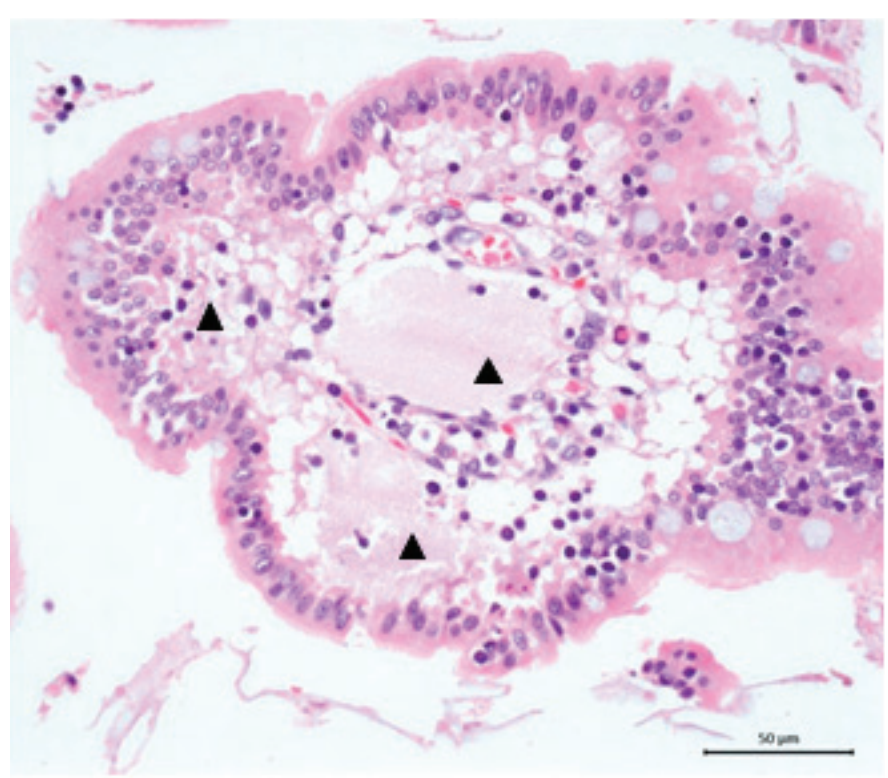

Fig.4. Photomicrography of an animal allocated in group I2H/R5H PBS 3D exhibiting mucosal edema (triangle).

Table 6. Results, in score, of the histological analysis for injury in jejunum mucosa belonging to New Zealand rabbits submitted to ischemia and reperfusion by clamping of the extramural peri-intestinal marginal artery/vein, according to Chiu et al. (1970)

\begin{tabular}{|c|c|c|c|c|}
\hline \multirow{2}{*}{ Rabbit } & \multicolumn{4}{|c|}{ Score for mucosa injury } \\
\hline & I2H/R5H MSC 3D & I2H/R5H MSC 7D & I2H/R5H PBS 3D & I2H/R5H PBS 7D \\
\hline 1 & 0 & 0 & 0 & 1 \\
\hline 2 & 0 & 0 & 2 & 1 \\
\hline 4 & 0 & 0 & 2 & 1 \\
\hline 5 & 0 & 0 & 1 & 1 \\
\hline 6 & 0 & 0 & 1 & 2 \\
\hline
\end{tabular}

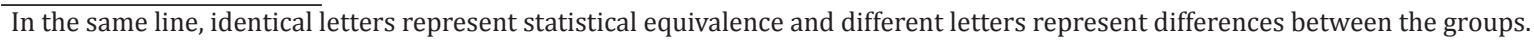

Table 7. Results, in score, of the histological analysis for presence of PMN in the jejunal mucosa belonging to New Zealand rabbits subjected to ischemia and reperfusion by clamping of the extramural peri-intestinal marginal artery/vein

\begin{tabular}{|c|c|c|c|c|}
\hline \multirow{2}{*}{ Rabbit } & \multicolumn{4}{|c|}{ Score for presence of PMN in mucosa } \\
\hline & I2H/R5H MSC 3D & I2H/R5H MSC 7D & I2H/R5H PBS 3D & I2H/R5H PBS 7D \\
\hline 1 & 2 & 3 & 2 & 0 \\
\hline 2 & 2 & 3 & 2 & 1 \\
\hline 3 & 2 & 4 & 1 & 1 \\
\hline 4 & 2 & 3 & 2 & 0 \\
\hline 5 & 1 & 3 & 1 & 1 \\
\hline 6 & 2 & 3 & 1 & 1 \\
\hline Median & $2^{\mathrm{ab}}$ & $3^{\mathrm{a}}$ & $1.5^{b}$ & $1^{\mathrm{b}}$ \\
\hline
\end{tabular}

In the same line, identical letters represent statistical equivalence and different letters represent differences between the groups. 
observed in the groups treated with PBS, most of which were classified as moderate (score 3 ). With these results, the group I2H/R5H MSC 3D was significantly different compared to the group I2H/R5H PBS 7D $(p<0.05)$. There were also differences between the group I2H/R5H MSC 7D in relation to the groups I2H/R5H PBS 3D and I2H/R5H PBS 7D ( $p<0.05 ; p<0.01)$. The other remaining alterations are presented in Table 10.

With the advance of the observational period, that is, seven days, regardless of the experimental group, there was a tendency for the organism to repair the injuries caused by ischemia and reperfusion, for example, the decreased mucosal edema shown in the group PBS 7D compared to the group PBS 3D.

The presence of polymorphonuclear (PMN) infiltration in the submucosa, was classified as moderate (score 3) in the groups treated with MSC, and incipient (score 1) in the groups treated with PBS. Statistically, the group I2H/R5H MSC 3D was significantly different compared to the groups I2H/R5H PBS 3D and I2H/R5H PBS 7D ( $p<0.05 ; p<0.01)$. Also, the group I2H/R5H MSC 7D differed significantly from

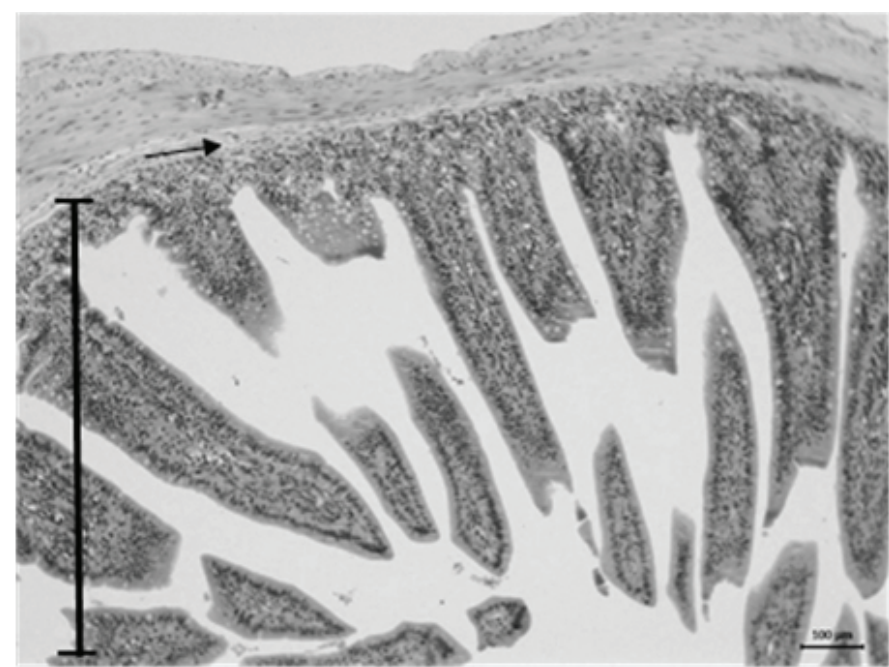

Fig.5. Photomicrography of an animal allocated in group I2H/R5H MSC 7D exhibiting preserved villi height (mucosa) (bar) and submucosa (arrow) with normal histological aspects.

Table 8. Results, in score, of the histological analysis for presence of mononuclear inflammatory process (MIP) in the jejunal mucosa belonging to New Zealand rabbits subjected to ischemia and reperfusion by clamping of the extramural peri-intestinal marginal artery/vein

\begin{tabular}{|c|c|c|c|c|}
\hline \multirow{2}{*}{ Rabbit } & \multicolumn{4}{|c|}{ Score for presence of MIP in mucosa } \\
\hline & I2H/R5H MSC 3D & I2H/R5H MSC 7D & I2H/R5H PBS 3D & I2H/R5H PBS 7D \\
\hline 1 & 1 & 2 & 1 & 2 \\
\hline 2 & 2 & 3 & 1 & 2 \\
\hline 3 & 2 & 3 & 1 & 2 \\
\hline 4 & 1 & 3 & 3 & 2 \\
\hline 5 & 1 & 3 & 3 & 2 \\
\hline 6 & 1 & 3 & 1 & 2 \\
\hline Median & $1^{\mathrm{a}}$ & $3^{b}$ & $1^{\mathrm{ab}}$ & $2^{\mathrm{ab}}$ \\
\hline
\end{tabular}

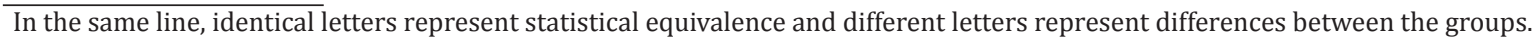

Table 9. Results, in score, of the histological analysis for lymphatic dilatation in the jejunal mucosa belonging to New Zealand rabbits subjected to ischemia and reperfusion by clamping of the extramural peri-intestinal marginal artery/vein

\begin{tabular}{ccccc}
\hline \multirow{2}{*}{ Rabbit } & \multicolumn{4}{c}{ Score for lymphatic dilatation in mucosa } \\
\cline { 2 - 5 } & I2H/R5H MSC 3D & I2H/R5H MSC 7D & I2H/R5H PBS 3D & 1 \\
I2H/R5H PBS 7D \\
\hline 1 & 1 & 0 & 0 & 1 \\
2 & 1 & 0 & 0 & 1 \\
4 & 0 & 0 & 2 & 1 \\
5 & 1 & 0 & 2 & 1 \\
6 & 1 & 0 & 2 & 1 \\
Median & 1 & 0 & $1.5^{\mathrm{b}}$ & $1^{\mathrm{b}}$
\end{tabular}

In the same line, identical letters represent statistical equivalence and different letters represent differences between the groups.

Table 10. Results, in score, of the histological analysis of submucosa edema in the jejunal submucosa belonging to New Zealand rabbits subjected to ischemia and reperfusion by clamping of the extramural peri-intestinal marginal artery/vein

\begin{tabular}{|c|c|c|c|c|}
\hline \multirow{2}{*}{ Rabbit } & \multicolumn{4}{|c|}{ Score for edema in submucosa } \\
\hline & I2H/R5H MSC 3D & I2H/R5H MSC 7D & I2H/R5H PBS 3D & I2H/R5H PBS 7D \\
\hline 1 & 1 & 0 & 3 & 3 \\
\hline 2 & 2 & 0 & 2 & 3 \\
\hline 3 & 0 & 0 & 2 & 3 \\
\hline 4 & 1 & 0 & 3 & 3 \\
\hline 5 & 1 & 1 & 3 & 3 \\
\hline 6 & 0 & 0 & 3 & 3 \\
\hline Median & $1^{\mathrm{ac}}$ & $0^{\mathrm{a}}$ & $3^{\mathrm{cb}}$ & $3^{b}$ \\
\hline
\end{tabular}

In the same line, identical letters represent statistical equivalence and different letters represent differences between the groups. 
the group I2H/R5H PBS 7D. The other remaining alterations are presented in Table 11.

During the mononuclear inflammatory process evaluation, focal areas of moderate (score 3) and light (score 2) presence were observed in the animals from the group I2H/R5H PBS 7D, however, the largest observation was of incipient presence (score 1). There was no significant difference between groups. The other remaining alterations are presented in Table 12.

Regarding the lymphatic dilation in submucosa, it was also observed that the group I2H/R5H MSC 7D was classified as absent (score 0) in most animals evaluated. Based on the results, the group I2H/R5H MSC 7D was significantly different from groups I2H/R5H PBS 3D and I2H/R5H PBS $7 \mathrm{D}(p<0.05 ; p<0.05)$. The other remaining alterations are presented in Table 13.

In the groups treated with MSC a large presence of mitotic cells in the crypt and interstitial region were also observed (Fig.6), as well as a slight decrease in density and shortening of the villi. However, these villi rarefactions were also strongly present in the groups treated with PBS.

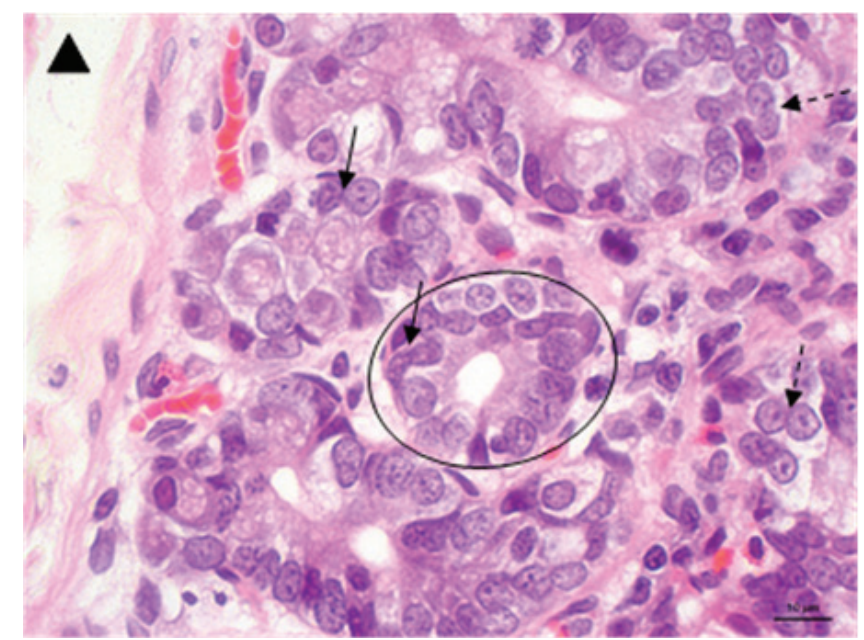

Fig.6. Photomicrography of an animal allocated in group I2H/R5H MSC 7D exhibiting mitotic cells in the crypt (arrows) and interstitial region (dotted arrows) of the intestinal mucosa (circle) (triangle = intestinal submucosa).

Table 11. Results, in score, of the histological analysis of presence of PMN in the jejunal submucosa belonging to New Zealand rabbits subjected to ischemia and reperfusion by clamping of the extramural peri-intestinal marginal artery/vein

\begin{tabular}{ccccc}
\hline \multirow{2}{*}{ Rabbit } & \multicolumn{4}{c}{ Score for presence of PMN in submucosa } \\
\cline { 2 - 5 } & I2H/R5H MSC 3D & I2H/R5H MSC 7D & I2H/R5H PBS 3D & 2 \\
I2H/R5H PBS 7D \\
\hline 1 & 3 & 2 & 1 & 1 \\
3 & 2 & 3 & 1 & 1 \\
4 & 3 & 3 & 2 & 1 \\
5 & 3 & 3 & 1 & 1 \\
6 & 3 & 2 & $1^{\text {bc }}$ & 1 \\
Median & 2 & $2.5^{\text {ac }}$ & $1^{\text {b }}$
\end{tabular}

In the same line, identical letters represent statistical equivalence and different letters represent differences between the groups.

Table 12. Results, in score, of the histological analysis of presence of MIP in the jejunal submucosa belonging to New Zealand rabbits subjected to ischemia and reperfusion by clamping of the extramural peri-intestinal marginal artery/vein

\begin{tabular}{ccccc}
\hline \multirow{2}{*}{ Rabbit } & \multicolumn{5}{c}{ Score for presence of MIP in submucosa } \\
\cline { 2 - 5 } & I2H/R5H MSC 3D & I2H/R5H MSC 7D & I2H/R5H PBS 3D & I2H/R5H PBS 7D \\
\hline 1 & 1 & 0 & 1 & 0 \\
2 & 1 & 0 & 1 & 2 \\
3 & 1 & 0 & 2 & 1 \\
4 & 1 & 0 & 1 & 2 \\
6 & 1 & 1 & 1 & 1 \\
Median & 1 & 0 & 1 &
\end{tabular}

Table 13. Results, in score, of the histological analysis of presence of lymphatic dilatation in the jejunal submucosa belonging to New Zealand rabbits subjected to ischemia and reperfusion by clamping of the extramural peri-intestinal marginal artery/vein

\begin{tabular}{|c|c|c|c|c|}
\hline \multirow{2}{*}{ Rabbit } & \multicolumn{4}{|c|}{ Score for lymphatic dilatation in submucosa } \\
\hline & I2H/R5H MSC 3D & I2H/R5H MSC 7D & I2H/R5H PBS 3D & I2H/R5H PBS 7D \\
\hline 1 & 1 & 0 & 0 & 0 \\
\hline 2 & 1 & 0 & 1 & 3 \\
\hline 3 & 1 & 0 & 1 & 2 \\
\hline 4 & 1 & 0 & 2 & 0 \\
\hline 5 & 1 & 1 & 1 & 1 \\
\hline 6 & 1 & 0 & 1 & 2 \\
\hline Median & $1^{\mathrm{ab}}$ & $0^{\mathrm{a}}$ & $1^{b}$ & $1.5^{b}$ \\
\hline
\end{tabular}

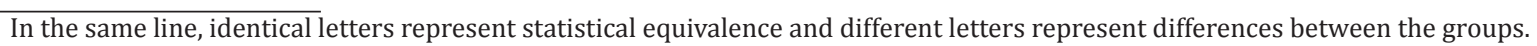




\section{DISCUSSION}

Several studies have demonstrated the beneficial effects of mesenchymal stem cell therapy originating from adipose tissue (MSC-Adp) in spinal cord tissue repair injuries (Barriga et al. 2013), myocardial infarction (Naaijkens et al. 2014), neurological disorders (Kemp et al. 2015), kidney damage (Chen \& Hou 2016), among others. However, studies suggesting therapies for intestinal disorders, using MSC-Adp are still scarce, and there for encouraging the present study.

The groups treated with MSC-Adp obtained lower scores of mucosa and submucosa injuries in the histological evaluation, in relation to the groups treated with PBS. The acceleration in the structural and functional recovery of the intestine, after the injury, can be explained by the potential of the MSC-Adp to differentiate into phenotypes of damaged tissue cells, increased angiogenesis in the injured organ (Caplan 2009), as well as production of growth factors and cytokines that resulted in increased tissue repair at the site of injury (Majumdar et al. 1998). Beneficial results using MSC therapy derived from bone marrow were also evidenced by Jiang et al. (2011) in a study with intestinal I/R in rats.

Only in the groups treated with PBS was a few haemorrhagic events in mucosa and submucosa observed, diverging from findings by Pagliosa et al. (2009), who observed that in the group where venous occlusion was performed in order to cause I/R damage to the jejunum in horses, there was a significant presence of hemorrhage and edema in the mucosa and submucosa. These alterations are explained as a result of hypoxia followed by reperfusion which will cause damage to the vascular endothelium, loss of permeability and extravasation of red blood cells, and effects of reactive oxygen species (ROS) (Dabareiner et al. 2001).

After three days of observation, edema as well as lymphatic dilatation, in the groups treated with MSC was less obvious than in the groups treated with PBS. These results suggest that soluble molecules released by the stem cells, upon contact with the injured tissue, triggers a series of beneficial cellular events in favor of tissue repair capable of minimizing vascular injury by regulating the capillary hydrostatic pressure and shortening edema formation (Nauta \& Fibbe 2007, Jiang et al. 2011, Monteiro et al. 2012).

Furthermore, the modulation potential of the inflammatory response caused by the MSC may be directly involved in lower scores of edema, lymphatic dilatation and hemorrhage, since the interaction of these cells on antigen presenting cells and on T lymphocytes, reducing and directing the inflammatory process in the lesion site (Nauta \& Fibbe 2007, Wan et al. 2008), a process that, when physiological, is essential to start the organism's repairing stages (Takahashi et al. 2007, Monteiro et al. 2010).

The moderate presence of polymorphonuclear cells in the lesion site of the animals treated with MSC-Adp compared to the absence in the PBS groups also demonstrates the ability of these MSCs to promote chemotaxis to the lesional bed, promoting immunomodulation and enhancing tissue repair (Caplan 2009).

Regarding the repair of injuries due to the time of evolution, this fact reinforces the injury caused in the body is not severe, and the resident cells are capable of assuming the repair process and the application of stem cells promote and anticipate the steps and reduce the morbidity of patients (Monteiro et al. 2012).

The amount of cells in mitotic activity present in the crypt and interstitial region, in which was intensely observed in the groups treated with MSC-Adp, and incipiently in the groups treated with PBS, can be explained by the fact that MSC stimulated cell mitosis in the lesion region of tissue- intrinsic progenitor cells (Caplan 2009). In the intestinal crypt region there is a population of resident intestinal stem cells (ISC) responsible for high rate cell production in different situations. The ISC are capable of differentiating into different cells from the intestinal structural constitution, and in injury situations, will respond promoting cellular mitosis in an attempt to repair the tissue (Barker et al. 2008, Chen et al. 2014).

\section{CONCLUSION}

The experimental model provoked lesions in the intestinal mucosa and submucosa. Infusion of stem cells attenuated the lesions caused by intestinal I/R in both MSC groups when compared to the groups treated with PBS, however further research is needed regarding its beneficial effect for this type of injury.

Acknowledgements.- The authors thank the Nacional Council of Technological and Scientific Development (CNPq - Process 552488/2011-9 and 483518/2011-5) and Fundação de Amparo à Pesquisa do Espírito Santo (FAPES) for granting the fellowships and financial support that permitted us to conduct this study.

\section{REFERENCES}

Abdeen S.M., Mathew T.C., Dashti H.M. \& Asfar S. 2011. Protective effects of green tea on intestinal ischemia-reperfusion injury. J. Nutr. 27(5):598-603. http://dx.doi.org/10.1016/j.nut.2010.05.014. PMid:21167681.

Alves G.E.S., Mendes H.M.F., Alves T.G.S., Faleiros R.R., Vasconcelos A.C., Santos R.L. \& Rio Tinto J.J.M. 2011. Hydrocortisone decreases apoptosis in jejunum of horses subjected to experimental ischemia and reperfusion. Pesq. Vet. Bras. 31(6):471-476. http://dx.doi.org/10.1590/S0100-736X2011000600002.

Avgerinos E.D., Kostopanagiotou G., Costopanagiotou C., Kopanakis N., Andreadou I., Lekka M., Nakos G. \& Smyrniotis V. 2010. Intestinal preconditioning ameliorates ischemia-reperfusion induced acute lung injury in rats: an experimental study. J. Surg. Res. 160(2):294-301. http:// dx.doi.org/10.1016/j.jss.2008.12.017. PMid:19439321.

Barker N., van de Wetering M. \& Clevers H. 2008. The intestinal stem cell. Gen. Develop. 22(14):1856-1864. http://dx.doi.org/10.1101/gad.1674008. PMid:18628392.

Barriga A., Medrano M., De-Juan J. \& Burgos J. 2013. Intravenous infusion of adult adipose tissue stem cells for repairing spinal cord ischaemic lesions. An experimental study on animals. Revta Esp. Cir. Ortop. Traumat. 57(2):8994. http://dx.doi.org/10.1016/j.recot.2013.01.001. PMid:23608207.

Ben D.F., Yu X.Y., Ji G.Y., Zheng D.Y., Lv K.Y., Ma B. \& Xia Z.F. 2012. TLR4 mediates lung injury and inflammation in intestinal ischemia-reperfusion. J. Surg. Res. 174(2):326-333.http://dx.doi.org/10.1016/j.jss.2010.12.005. PMid:21392794.

Boybeyi Ö., Gunal Y.D., Atasoy P., Kisa U. \& Aslan M.K. 2014. The effect of colchicine and low-dose methotrexate on intestinal ischemia/ reperfusion injury in an experimental model. J. Ped. Surg. 49(10):1471-1474. http:// dx.doi.org/10.1016/j.jpedsurg.2014.01.057. PMid:25280648.

Caplan A.I. 2009. Why are MSCs therapeutic? New data: new insight. J. Pathol. 217(2):318-324. http://dx.doi.org/10.1002/path.2469. PMid:19023885. 
Chen C. \& Hou J. 2016. Mesenchymal stem cell-based therapy in kidney transplantation. Stem Cell Res. Ther. 7(1):16. http://dx.doi.org/10.1186/ s13287-016-0283-6. PMid:26852923.

Chen Y., Lee S., Tsai Y. \& Tseng S. 2014. Ischemic preconditioning increased the intestinal stem cell activities in the intestinal crypts in mice. J. Surg. Res. 187(1):85-93. http://dx.doi.org/10.1016/j.jss.2013.10.001. PMid:24176207.

Chiu C.J., Scott H.J. \& Gurd F.N. 1970. Intestinal mucosal lesion in lowflow states. II. The protective effect of intraluminal glucose as energy substrate. Arch. Surg. 101(4):484-488. http://dx.doi.org/10.1001/ archsurg.1970.01340280036010. PMid:5311679.

Dabareiner R.M., Sullins K.E., White N.A. \& Snyder J.R. 2001. Serosal injury in the equine jejunum and ascending colon after ischemia reperfusion or intraluminal distention and decompression. Vet. Surg. 30(2):114-125. http://dx.doi.org/10.1053/jvet.2001.21393. PMid:11230765.

Dabareiner R.M., White N.A., Snyder J.R., Feldman B.F. \& Donaldson L.L. 2005. Effects of Carolina rinse solution, dimethyl sulfoxide, and 21- aminosteroid, U-74389G, on microvascular permeability and morphology of the equine jejunum after low-flow ischemia and reperfusion. Am. J. Vet. Res. 66(3):525536. http://dx.doi.org/10.2460/ajvr.2005.66.525. PMid:15822599.

Gao C., Chai W., Xu L., Zhang G., Zhang H., Han L. \& Sun X. 2006. Protective effects of hyperoxygenated solution preconditioning on intestinal ischemiareperfusion injury in rabbits. J. Surg. Res. 135(2):268-274. http://dx.doi. org/10.1016/j.jss.2006.03.019. PMid:16863653.

Giordano A., Galderisi U. \& Marino I.R. 2007. From the laboratory bench to the patient's bedside: an update on clinical trials with mesenchymal stem cells. J. Cell. Physiol. 211(1):27-35. http://dx.doi.org/10.1002/jcp.20959. PMid:17226788.

Greca F.H., Gonçalves N.M., Souza Filho Z.A., Noronha Ld., Silva R.F. \& Rubin M.R. 2008. The protective effect of methylene blue in lungs, small bowel and kidney after intestinal ischemia and reperfusion. Acta Cir. Bras. 23(2):149-156. http://dx.doi.org/10.1590/S0102-86502008000200007. PMid:18372960.

Hung W.T., Chen Y., Tseng S.H., Li H.L. \& Chen C.K. 2004. Fetal bovine serum suppresses apoptosis in the small intestine after total ischemia and reperfusion in mice. J. Ped. Surg. 39(7):1077-1083. http://dx.doi. org/10.1016/j.jpedsurg.2004.03.047. PMid:15213903.

Itagaki S., Oikawa S., Ogura J., Kobayashi M., Hirano T. \& Iseki K. 2010. Protective effects of quercetim-3-rhamnoglucoside (rutin) on ischemia-reperfusion injury in rat small intestine. Food Chem. 118(2):426-429. http://dx.doi. org/10.1016/j.foodchem.2009.04.103.

Jiang H., Qu L., Li Y., Gu L., Shi Y., Zhang J., Zhu W. \& Li J. 2011. Bone marrow mesenchymal stem cells reduce intestinal ischemia/reperfusion injuries in rats. J. Surg. Res. 168(1):127-134. http://dx.doi.org/10.1016/j. jss.2009.07.035. PMid:19932900.

Kaszaki J., Wolfárd A., Szalay L. \& Boros M. 2006. Pathophysiology of ischemia-reperfusion injury. Trans. Proc. 38(3):826-828. http://dx.doi. org/10.1016/j.transproceed.2006.02.152. PMid:16647484.

Kemp K., Redondo J., Mallam E., Scolding N. \& Wilkins A. 2015. The use of mesenchymal stem cells for treating neurodegenerative diseases. Stem Cells and Cancer Stem Cells 13:3-20. http://dx.doi.org/10.1007/97894-017-7233-4_1.

Kostopanagiotou G., Avgerinos E., Costopanagiotou C., Arkadopoulos N., Andreadou I., Diamantopoulou K., Lekka M., Smyrniotis V. \& Nakos G. 2007. Acute lung injury in a rat model of intestinal Ischemia-Reperfusion: the potential time depended role of phospholipases A2. J. Surg. Res. 147(1):108116. http://dx.doi.org/10.1016/j.jss.2007.07.023. PMid:17981297.

Kubiak B.D., Albert S.P., Gatto L.A., Snyder K.P., Maier K.G., Vieau C.J., Roy S. \& Nieman G.F. 2010. Peritoneal negative pressure therapy prevents multiple organ injury in a chronic porcine sepsis and ischemia/reperfusion model. Shock 34(5):525-534. http://dx.doi.org/10.1097/SHK.0b013e3181e14cd2. PMid:20823698.
Ma L., Wang G., Chen Z., Li Z., Yao J., Zhao H., Wang S., Ma Z., Chang H. \& Tian X. 2014. Modulating the p66shc signaling pathway with protocatechuic acid protects the intestine from ischemia-reperfusion injury and alleviates secondary liver damage. Scient. World J. 2014:387640. PMid:24757420.

Majumdar M.K., Thiede M.A., Mosca J.D., Moorman M. \& Gerson S.L. 1998. Phenotypic and functional comparison of cultures of marrow-derived mesenchymal stem cells (MSCs) and stromal cells. J. Cell. Physiol.176(1):5766. http://dx.doi.org/10.1002/(SICI)1097-4652(199807)176:1<57::AIDJCP7>3.0.CO;2-7. PMid:9618145.

Manieri N.A. \& Stappenbeck T.S. 2011. Mesenchymal stem cell therapy of intestinal disease: are their effects systemic or localized? Curr. Opin. Gastroenterol. 27(2):119-124. http://dx.doi.org/10.1097/MOG.0b013e3283423f20. PMid:21150589.

Meirelles L.S., Caplan A.I. \& Nardi N.B. 2008. In search of the in vivo identity of mesenchymal stem cells. Stem Cells 26(9):2287-2299. http://dx.doi. org/10.1634/stemcells.2007-1122. PMid:18566331.

Monteiro B.S., Argolo Neto N.M. \& Del Carlo R.J. 2008. Terapia celular em reparação óssea: aplicação clínica de células-tronco mesenquimais. Ciênc. Vet. Tróp. 11:95-100.

Monteiro B.S., Argolo Neto N.M. \& Del Carlo R.J. 2010. Células-tronco mesenquimais. Ciência Rural 40(1):238-245. http://dx.doi.org/10.1590/ S0103-84782010000100040.

Monteiro B.S., Argôlo-Neto N.M., Nardi N.B., Chagastelles P.C., Carvalho P.H., Bonfá L.P., Filgueiras R.R., Reis A.S. \& Del Carlo R.J. 2012. Treatment of critical defects produced in calvaria of mice with mesenchymal stem cells. Anais Acad. Bras. Ciênc. 84(3):841-851. http://dx.doi.org/10.1590/ S0001-37652012000300026. PMid:22886167.

Naaijkens B.A., van Dijk A., Kamp O., Krijnen P.A., Niessen H.W. \& Juffermans L.J. 2014. Therapeutic Application of Adipose Derived Stem Cells in Acute Myocardial Infarction: Lessons from Animal Models. Stem Cell Rev. Rep. 10(3):389-398. PMid:24577790.

Nauta A.J. \& Fibbe W.E. 2007. Immunomodulatory properties of mesenchymal stromal cells. Blood 110(10):3499-3506. http://dx.doi.org/10.1182/ blood-2007-02-069716. PMid:17664353.

Oldenburg W.A., Lau L.L., Rodenberg T.J., Edmonds H.J. \& Burger C.D. 2004. Acute mesenteric ischemia: a clinical review. Archs Intern. Med. 164(10):10541062. http://dx.doi.org/10.1001/archinte.164.10.1054. PMid:15159262.

Pagliosa G.M., Alves G.E.S., Faleiros R.R., Matos J.R.T., Torres M.B., Mendes H.M.F. \& Costa R.S. 2009. Utilização da glutamina no tratamento de lesões de isquemia e reperfusão no jejuno em equinos. Pesq. Vet. Bras. 29(3):246252. http://dx.doi.org/10.1590/S0100-736X2009000300010.

Paiva L.A.F., Gurgel L.A., Campos A.R., Silveira E.R. \& Rao V.S. 2004. Attenuation of ischemia/reperfusion-induced intestinal injury by oleo-resin from Copaifera langsdorffii in rats. Life Sci. 75(16):1979-1987. http://dx.doi. org/10.1016/j.lfs.2004.05.011. PMid:15306165.

Pittenger M.F., Mackay A.M., Beck S.C., Jaiswal R.K., Douglas R., Mosca J.D., Moorman M.A., Simonetti D.W., Craig S. \& Marshak D.R. 1999. Multilineage potential of adult human mesenchymal stem cells. Science 284(5411):143147. http://dx.doi.org/10.1126/science.284.5411.143. PMid:10102814.

Ritz J.P., Germer C.T. \& Buhr H.J. 2005. Prognostic factors for mesenteric infarction: multivariate analysis of 187 patients with regard to patient age. Annals Vasc. Surg. 19(3):328-334. http://dx.doi.org/10.1007/s10016005-0005-5. PMid:15818455.

Rocha B.C., Mendes R.R.S., Lima G.V., Albuquerque G.S., Araújo L.L., Jesus M.N.S., Santos W.L.C. \& Carreiro M.C. 2012. Modelo experimental de isquemia/ reperfusão intestinal por clampeamento de aorta abdominal em ratos Wistar. Revta Col. Bras. Cir. 39(3):207-210. http://dx.doi.org/10.1590/ S0100-69912012000300008.

Rowe E.L. \& White N.A. 2002. Reperfusion injury in the equine intestine. Clin. Tech. Equine Pract. 1(3):148-162. http://dx.doi.org/10.1053/ ctep.2002.35578. 
Takahashi K., Tanabe K., Ohnuki M., Narita M., Ichisaka T., Tomoda K. \& Yamanaka S. 2007. Induction of pluripotent stem cells from adult human fibroblasts by defined factors. Cell 131(5):861-872. http://dx.doi.org/10.1016/j. cell.2007.11.019. PMid:18035408.

Vasileiou I., Kalimeris K., Nomikos T., Xanthopoulou M.N., Perrea D., Agrogiannis G., Nakos G. \& Kostopanagiotou G. 2012. Propofol Prevents Lung Injury Following Intestinal Ischemia-Reperfusion. J. Surg. Res. 172(1):146-152. http://dx.doi.org/10.1016/j.jss.2010.07.034. PMid:20855084.

Vollmar B. \& Menger M.D. 2011. Intestinal ischemia/reperfusion: microcirculatory pathology and functional consequences. Langenbeck's Archs Surg. 396(1):13-29. http://dx.doi.org/10.1007/s00423-010-0727-x. PMid:21088974.
Wan C.D., Cheng R., Wang H.B. \& Liu T. 2008. Immunomodulatory effects of mesenchymal stem cells derived from adipose tissues in a rat orthotopic liver transplantation model. Hepatobil. Pancr. Dis. Int. 7(1):29-33. PMid:18234635.

Yasuhara H. 2005. Acute mesenteric ischemia: the challenge of gastroenterology. Surg. Today 35(3):185-195. http://dx.doi.org/10.1007/s00595-0042924-0. PMid:15772787.

Yurdakan G., Tekin I.O., Comert M., Acikgoz S. \& Sipahi E.Y. 2012. The presence of oxidized low-density lipoprotein and inducible nitric oxide synthase expression in renal damage after intestinal ischemia reperfusion. Kaohsiung J. Med. Sci. 28(1):16-22. PMid:22226057. 